\title{
Effectiveness of Employees Compensation-Measured by Customer Satisfaction (Study Conducted at Private Banks of Ethiopia_Snnpr_Wolaita Sodo Branches)
}

\section{Mengistu Matino*}

Department of Management, College of Business and Economics, Wolaita Sodo University, Wolayta Sodo, Ethiopia

\begin{abstract}
Employee compensation refers to the benefits: cash, vacation, etc. that an employee receives in exchange for the service they provide to their employer. Employee compensation is generally one of the largest costs or expenses for any organization. It is the total amount an employee can expect to receive when working for an organization The effectiveness of employee's Compensation at Wolaita Sodo private banks are one of the work which have been doing or considering the main duties with the main sectors of banking to run market and marketing activities, construction sectors, and other complex business sectors by the help of an experts. The purpose of this study is to analyse some of the most important internal and external factors that affect the effectiveness of compensation on working condition or benefit of private banks in Wolaita Sodo City. In addition to this, the study evaluate the effects of firms' ability to pay, employee productivity, compensation by laws and regulation, reward strategy as well as job requirements on the compensation system. Primary and secondary data are the main values that applied in this research study. To determine the study population, the researcher has used the stratified sampling method. The data collected from the whole respondents and used descriptive statistics. The data analysed using descriptive statistics such as, percentage, frequency distribution table and standard deviation and presented by using tables.
\end{abstract}

The result from the analysis show that, many of internal and external variables have significant impact on Private banks compensation, while very few of them have no significant impact on banks compensation.

This study is relevant to academician, researchers and industry people who work in the field of private banks. Besides on these research findings, the private bank heads of the Wolaita Sodo with concerned bodies may conduct the extra benefit by the help of the special significant variables and the sector should take care especially, the current government business systems. In addition to this, the other researcher may come up with different projects that let the workers to stay connected with the working organization.

Keywords: Internal factors; External factors; Compensation; Workloads; Descriptive statistics

\section{Background of the Study}

In any profit-oriented organization, employment relationship is seen as an exchange process where employees provide inputs in terms of skills and expertise in return for various compensations from the employer. From the perspective of the employee, pay has an important influence on Standard of living, status, and security. Less direct forms of compensation such as health care, pensions and other benefits also have an important impact on employees' well-being. From the employer's point of view, compensation is both a major cost of doing business that needs to be controlled and an investment that must generate adequate returns in terms of employee attitudes, skills, behaviours and organization performance [1].

Compensation is money that someone who has experienced inconvenience, loss, or suffering claims from the person or organization responsible or from the state. Compensation is cash or non-cash rewards employees receive in change for their work. When the system is properly administered employees are more likely to be satisfied and motivated to contribute the achievement of organizational objectives but when employees perceive their compensation to be not appropriate performance, motivation and satisfaction may decline dramatically $[2,3]$. Compensation refers to all form of financial returns and tangible benefits that employees receive as part of an employment relationship [4].

Compensation is adequate and equitable remuneration of personnel for their contribution to the achievement of organizational objectives [5]. The study concerns different types of term such as payment that employee receive which includes different types of compensation, bones, salary and wages. It also includes different types of financial compensation that is called benefits and service which consists insurance payment, retirement plan payment for time that is not worked. According to Benardin [6], in organization compensation is to be effective, it have to include the following adequate, equitable, balanced, and cost effective, security pay, incentive providing pay and acceptable to the employees. Some researcher argues that paying is tied with performance, the intrinsic reward that a person gets from job.

The study gives especial focus on nine private banks in Wolaita Sodo City includes: Abyssinia Bank, Abay bank, Awash Bank, Brihan Bank, Dashen Bank, Debub Global Bank, Hibret Bank and Nib Bank, Oromiya Bank. The banks are working best for their survival and to stay connected with different benefits. These all have expert/workers

*Corresponding author: Matino M, Department of Management, College of Business and Economics, Wolaita Sodo University, Wolayta Sodo, Ethiopia, Tel: +2519-16852765; E-mail: mmew2016@gmail.com

Received January 18, 2018; Accepted February 26, 2018; Published March 05 2018

Citation: Matino M (2018) Effectiveness of Employees Compensation-Measured by Customer Satisfaction (Study Conducted at Private Banks of Ethiopia Snnpr Wolaita Sodo Branches). Bus Eco J 9: 341. doi: 10.4172/2151-6219.1000341

Copyright: (c) 2018 Matino M. This is an open-access article distributed under the terms of the Creative Commons Attribution License, which permits unrestricted use, distribution, and reproduction in any medium, provided the original author and source are credited. 
Citation: Matino M (2018) Effectiveness of Employees Compensation-Measured by Customer Satisfaction (Study Conducted at Private Banks of Ethiopia_Snnpr_Wolaita Sodo Branches). Bus Eco J 9: 341. doi: 10.4172/2151-6219.1000341

who handled the customers. These workers need compensation to stay long period with that bank by gaining according to their performance. So that, this is a research tries to find out the factors that affect the workers to go out and seek the other banks or related sectors.

\section{Statement of the Study}

\section{Scholar arguments}

Compensation by nature most complex form and its system contains many different decision rules, guidelines, and processes for determining pay level and pay structure. The pay Structure is the relative differential among various jobs within the organization and how this is determined. The relative amount of compensation assigned to each job compared to the job market [7].

For most employers the workers compensation claim process occurs behind the scenes. Many transactions between the injured employee and private bank companies are carried out unknown to the employer. However there are many common problems associated with the claim process that ultimately have an impact on the employer's workers compensation program and pricing.

Compensation plays an important role in an organizations ability to attract and retain qualified and high performance workers. If employees will compensate in good manner, they will create good working habit and achieve goals of the organization [8].

However, if the compensation is not practiced in a good manner, it lowers employee's performance; they will have low productivity and creates employees' carelessness and becomes the cause of interruption of customer service [6]

In consideration of these problems, I intended to conduct the research on compensation effectiveness at private banks in Wolaita Sodo branch whether their compensation plan/system that they are giving is effective or not.

\section{Research question}

- What are the factors that affect compensations effective at Wolaita Sodo private banks?

- Is the private banks compensation is effective?

- What are the results if compensation plan is effective and ineffective at banks?

\section{Specific objective}

○ To identify factors that affecting employee's compensation effectiveness at their plan.

- To check the effectiveness of employees compensation plan.

- To show the results when private banks during compensating and not compensating their experts/works.

\section{Significant of the study}

The study on the effectiveness of employee's compensation plan would have its own significances and it:

- Positive impact on the efficiency and results produced by employees.

- Encourage the employees to perform better and achieve the standards fixed.

$\circ$ Enhance the process of job evaluation.
- Help in setting up an ideal job evaluation and the set standards would be more realistic and achievable.

- Raise the morale, efficiency and cooperation among the workers.

- Help management in complying with the various labour acts.

- Provides platform for happy and satisfied workforce.

\section{Scope of the study}

The research is delimited on the effectiveness of compensation plan around Wolaita Sodo City private banks. It contains internal and external compensation problems as general. It includes nine private banks which are giving the same functions by help of an expert.

\section{Research methodology}

Target population: The employees who work is in private Banks in Wolaita Sodo branch was the target population of the study.

Research designs: The representation of research design basis and the element selection technique used the sample that should be non-probability sampling. Sample design element selection technique was restricted sampling probability of stratified sampling [9]. The real figure of each bank workers/ experts numbers as follows: Abyssinia Bank $=11=\mathrm{N} 1$, Abay Bank=15=N2, Awash Bank=14=N3, Brihan Bank $=17=N 4$, Dashen Bank $=35=N 5$, Debub Global Bank $=6=\mathrm{N} 6$, Hibret Bank=16=N7, Nib Bank=10=N8, Oromiya Bank=21=N9. Suppose, I want a sample size $\mathrm{n}=50$ to be drawn from a proportion of size $\mathrm{N}=135$ which is divided in to nine strata of sizes: $\mathrm{N} 1=11, \mathrm{~N} 2=17$, $\mathrm{N}=6, \mathrm{~N} 4=35, \mathrm{~N} 5=21, \mathrm{~N} 6=15, \mathrm{~N} 7=10, \mathrm{~N} 8=16$, and $\mathrm{N} 9=14$. Adapting Proportional allocation, I got the sample sizes as under for the different strata.

\section{Sampling methods of the study}

Stratified sampling method was used to collect data form total population [10-13]. The reason is the total populating was not manageable to get acquire relevant information from each employee in the organization.

\section{Types and sources of data}

Both primary and secondary sources used to get the required information. The primary data was collected from employees through questionnaires and though interview, which were both structured and uninstructed.

\section{Data discussion and presentation}

The analysis, interpretation and presentations of findings are collected from employees and managers through questionnaire and interview. As that, all the (53) fifty three questionnaires were distributed and collected from respondents and clear and deep interviews were presented to the manager. Having this; I presented the data in the following manner:

Gender: The above table shows that, 54\% (29) respondents were male and the remaining $46 \%$ (24) were females. Therefore, the researcher argues that dominantly males were involved in the private bank organization.

Age: Based on the above table out of total respondents, $4 \%$ (2) of respondents were between $21-30$ years, $71 \%$ (38) of respondents were between $31-40$ years, $25 \%$ (13) of the respondents were 40 and above. 
Citation: Matino M (2018) Effectiveness of Employees Compensation-Measured by Customer Satisfaction (Study Conducted at Private Banks of Ethiopia_Snnpr_Wolaita Sodo Branches). Bus Eco J 9: 341. doi: 10.4172/2151-6219.1000341

Form this; researcher concludes that most respondents were at age range between $31-40$ years.

Education: As indicated in the above table from the total respondents $41(77 \%)$ are degree holders and the remaining $12(23 \%)$ were master degree and above. Hence, the organization has more degree holder employees.

Work experience: According to the data above 4 (8\%) of employees have work experience 2-3 years and 49 (92\%) of respondents have work experience above 3 years. From this, the researcher generalized that organization is much more filled by employees who have long work experience.

Salary: From the above table all respondents were get $0(0 \%)$ are gaining below $2000 \mathrm{ETB}, 4$ (8\%) of the respondents lies between 2000 $6000,28(53 \%)$ of the respondent are getting 6000-8000 and $21(39 \%)$ of the respondents were lies between above 8000 ETB. From this, the researcher concludes most of employees have salary between 6000 $8000 \mathrm{ETB}$

Based on the above data (Table 1) 11 (20.75\%) of respondents where gat benefits of health plan. Out of the total $4(7.74 \%)$ of respondents where got disability protection plan benefits, and $30(56.6 \%)$ of respondents answered they get Retirement Insurance. Lastly, 8 (15.09\%) get benefit of bonuses at the end of the year according to their performance total balance sheet recorded. This indicates that most employees get Retirement Insurance plan of the benefit and secondly, medical or health benefits [14].

As shown in the above (Table 2), $31(60 \%)$ of respondents get

\begin{tabular}{|c|c|c|c|}
\hline \multirow[t]{2}{*}{ Background Variables } & \multirow[t]{2}{*}{ Item } & \multicolumn{2}{|c|}{ Respondents } \\
\hline & & $\mathbf{n}$ & $\%$ \\
\hline \multirow[t]{3}{*}{ Sex } & Male & 29 & 54 \\
\hline & Female & 24 & 46 \\
\hline & Total & 53 & 100 \\
\hline \multirow[t]{4}{*}{ Age range } & $21-30$ & 2 & 4 \\
\hline & $31-40$ & 38 & 71 \\
\hline & 40 and above & 13 & 25 \\
\hline & Total & 53 & 100 \\
\hline \multirow[t]{3}{*}{ Education level } & Degree & 41 & 77 \\
\hline & Master and above & 12 & 23 \\
\hline & Total & 53 & 100 \\
\hline \multirow[t]{3}{*}{ Work experience } & 2-3 year & 4 & 8 \\
\hline & Above 3 year & 49 & 92 \\
\hline & Total & 53 & 100 \\
\hline \multirow[t]{5}{*}{ Salary ranges } & Below 2000 & 0 & 0 \\
\hline & $2000-6000$ & 4 & 8 \\
\hline & $6000-8000$ & 28 & 53 \\
\hline & Above 8000 & 21 & 39 \\
\hline & Total & 53 & 100 \\
\hline
\end{tabular}

Table 1: Personal information of the workers (Respondents).

\begin{tabular}{|l|c|c|}
\hline \multicolumn{1}{|c|}{ Variables/factors } & \multicolumn{2}{c|}{ Number of respondents } \\
\hline Types of benefit/Non-financial Given & $\mathbf{n}$ & Percentage \% \\
\hline Health Insurance & 11 & 20.75 \\
\hline Disability Insurance & 4 & 7.74 \\
\hline Retirement Insurance & 30 & 56.60 \\
\hline Bonus Benefits & 8 & 15.09 \\
\hline Total & 53 & 100 \\
\hline
\end{tabular}

Source: Data 2017

Table 2: Types of Non-monetary benefits given. benefit sometimes, 5 (8\%) of respondents get regularly and 17 (32\%) of the respondents get the benefits frequently. Whatever the bank sector organizations are profit oriented that they worries not to pay extra benefits to their works. This shows most of employees in the organizations earn benefits sometimes.

Based on the above (Table 3) No. 1, 25 (47\%) of respondents responded that they get equitable benefits or services in the organization and 28 (53\%) of respondents responded that the benefits are not given equitably in the organization. This indicates that most employees of the organization get equitable benefit.

Based on the above (Table 3) No. 2, 23 (43\%) of respondents responded that they get balanced benefits in comparison with the same organization or services in the organization and $30(57 \%)$ of respondents responded that the benefits are not given the same as in the other organization. This indicates that most employees of the organization paying or giving unbalanced payments of the benefit [15]

Based on the above (Table 3) No. 3, 27 (50.1\%) of respondents responded that they getting fair benefits or services in the organization and 26 (49.9\%) of respondents responded that the benefits are not given fairly in an organizations. This indicates that most employees of the organization get fair benefit.

Based on the above (Table 3) No. 4, 15 (28\%) of respondents responded that they getting effective motivation, benefits or services in the organization and $38(72 \%)$ of respondents responded that the benefits are not given in effective way in the organizations. This indicates that most employees of the organization get un effective benefit [16].

Based on the above (Table 4) No. 5, 23 (43\%) of respondents responded that they get high level of satisfactory rewards, benefits or services in the organization and $30(57 \%)$ of respondents responded that the benefits are not given in highly satisfactory way to the employees in an organization. This indicates that most employees of the organization should not get high rewards, benefit or compensations.

Based on the above (Table 4) No. 6, 42 (79\%) of respondents responded that the government regulation affect highly their compensations, benefits or services in the organization and $11(21 \%)$ of respondents responded that it may not affect highly the benefits or compensation in an organizations. This indicates that most employee's compensation activities or deliverance not affected by the government regulations, proclamation, procedures and other duet to their selfindependent working structures [17].

Based on the above (Table 4) No. 7, 26 (49.9\%) of respondents responded that they expect high work group influences on benefits or services in the organization and 27 (50.1\%) of respondents responded that the benefits are not influenced highly in benefits or compensation in the organization. This indicates that most employees of the organization not highly expected on high work group influences on benefit giving.

\begin{tabular}{|l|c|c|}
\hline \multicolumn{1}{|c|}{ Variables/factors } & Respondents \\
\hline Provision of Benefits Given & n & $\%$ \\
\hline Sometimes & 31 & 60 \\
\hline Regularly & 5 & 8 \\
\hline Frequently & 17 & 32 \\
\hline Total & 53 & 100 \\
\hline Source: Data 2017 & & \\
\hline
\end{tabular}

Table 3: How often benefits are provided excluding basic salary. 
Citation: Matino M (2018) Effectiveness of Employees Compensation-Measured by Customer Satisfaction (Study Conducted at Private Banks of Ethiopia_Snnpr_Wolaita Sodo Branches). Bus Eco J 9: 341. doi: 10.4172/2151-6219.1000341

Page 4 of 5

\begin{tabular}{|c|c|c|c|c|}
\hline \multirow[t]{2}{*}{ No. } & \multirow[t]{2}{*}{ Variables/factors } & \multicolumn{3}{|c|}{ Respondents } \\
\hline & & Yes=n \& \% & No=n \& \% & Total n \& \% \\
\hline 1 & Availability of Equitable Benefits Service & $25(47 \%)$ & $28(53 \%$ & $53(100 \%)$ \\
\hline 2 & Balance of benefits in comparison with the same organization & $23(43 \%)$ & $30(57 \%)$ & $53(100 \%)$ \\
\hline 3 & The fairness of benefits & $27(50.1 \%)$ & $26(49.9 \%)$ & $53(100 \%)$ \\
\hline 4 & Effectiveness of motivation & $15(28 \%)$ & $38(72 \%)$ & $53(100 \%)$ \\
\hline 5 & High level of satisfactory Rewards & $23(43 \%)$ & $30(57 \%)$ & $53(100 \%)$ \\
\hline 6 & Effect of gov'nt regulation is high & $42(79 \%)$ & $11(21 \%)$ & $53(100 \%)$ \\
\hline 7 & Expectation of high group influence & $26(49.9 \%)$ & $27(50.1 \%)$ & $53(100 \%)$ \\
\hline 8 & Favorability of working condition & $25(47 \%)$ & $28(53 \%)$ & $53(100 \%)$ \\
\hline
\end{tabular}

Table 4: All variables/factors that influence the compensations.

\begin{tabular}{|c|c|c|}
\hline \multirow{2}{*}{$\begin{array}{l}\text { Variables/factors } \\
\text { Degree of Satisfaction on payable salary }\end{array}$} & \multicolumn{2}{|c|}{ Respondents } \\
\hline & $\mathbf{n}$ & Percentage \\
\hline Highly satisfied & 19 & 39 \\
\hline Satisfied & 21 & 40 \\
\hline Unsatisfied & 23 & 43 \\
\hline Highly unsatisfied & 0 & 0 \\
\hline Total & 53 & 100 \\
\hline
\end{tabular}

Table 5: Satisfaction with basic salary.

\begin{tabular}{|c|c|c|c|c|c|c|}
\hline \multirow[t]{2}{*}{ No. } & \multirow[t]{2}{*}{ Variables/factors } & \multicolumn{5}{|c|}{ Respondents } \\
\hline & & Very high=n $\%$ & High=n \& \% & Low=n \% & Very low=n \& \% & Total=n \& \% \\
\hline 1 & Payment according to contribution & $11(21 \%)$ & $18(40 \%)$ & $24(45 \%)$ & $0(0 \%)$ & $53(100 \%)$ \\
\hline 2 & Level of Compensation satisfaction & $3(6 \%)$ & $24(45 \%)$ & $26(49 \%)$ & $0(0 \%)$ & $53(100 \%)$ \\
\hline
\end{tabular}

Table 6: Payment evaluation based on contribution and the sacredness of the pay.

According to the above (Table 4) No. 8, 25 (47\%) of respondents responded that they get favourable working conditions or services in the organization and 28 (53\%) of respondents responded that the working conditions are not favourable to them in their organizations. This indicates that, most employees of the organization working not under the favourable conditions [18-21].

Based on the above data, 19 (39\%) of respondents were highly satisfied with their basic salaries, 21 (40\%) of respondents were satisfied by their basic salaries and $23(43 \%)$ of the respondents were not satisfied with their basic payable salaries. This indicates that most respondents were unsatisfied by their basic salary.

The data in the above (Table 5) No.1 indicates that, 24 (45\%) of respondents respond that the payment is according to their contribution and it is low to them and $11(21 \%)$ of the respondent said that they get it according to their contribution called very high. The remaining 18 (40\%) of respondents respond that the payment is high according to their contribution. This indicates the payment is mostly according to their contribution.

Based on the above data (Table 6), No. 2, 26 (49\%) of respondents respond that the organization compensation is low their basic needs and wants. While the remaining $24(45 \%)$ of respondents respond the organization compensation is a little bit satisfying basic needs and wants. This a data indicate that mostly the organization compensation is unsatisfying basic needs and wants.

\section{Interviews for the Manager}

The researcher conducted interview from the manager of the organization and got the following result: How your organization compensation is implemented?
The organization compensation system is implemented by the order of head office means it is centralized system of compensation.

What are problems arise from employees related to compensation?

The managers described the problems that are faced on employees with related to compensation is decrease employees moral and dissatisfaction is sometimes occur, because of employees are not compensated based on performance.

What are factor that affect the organization Compensation system?

Managers described that there are various factors and influences to compensation of the organization. Those factors are internal or external factors:

Government regulations: as indicated by the manager it affects the compensation changed or increased. So government affects the organization compensation and taxes also affect the organizations compensation. Mangers: decrease employees compensation because of all managers of dashed bank is share-holders so increase their share instead of employee's compensation.

Organization ability to pay: organization that have high profit and enjoy good cash management the organization can increase compensation. When the organization can decrease profit, some benefits are cut because of funds are not available. The bank pay low bonus because of low profit.

\section{Summary}

According to the data collected by different techniques, the research findings presented and summarized as follows:

- The majority of respondents are males which is $54 \%$, most of 
Citation: Matino M (2018) Effectiveness of Employees Compensation-Measured by Customer Satisfaction (Study Conducted at Private Banks of Ethiopia_Snnpr_Wolaita Sodo Branches). Bus Eco J 9: 341. doi: 10.4172/2151-6219.1000341

the respondents age lies 38 (71\%) between $31-40$ yours, most employees 41 (71\%) have degree holder employees, majority of respondents have long work experience, most employees $28(53 \%)$ salary greater than $6000 \mathrm{ETB}$, most of employees get retirement benefit at first hand and health as second.

- The majority of respondents in the organization earn benefit sometimes, most of employees of the organization get equitable benefits, mostly the organization give rewards are in unbalanced way, majority of respondents are satisfied by their basic salary, basic salary is mostly unfair with related to similar organizations, payment is mostly according to employee contribution, mostly the organization compensation is satisfying basic need and wants, work group influences the organization compensation.

- Government regulation can affect the compensation.

- Most of employees do their work in a favourable condition.

- The compensation system is implemented by head office or centralized way.

- The problem is faced by employee means decreases moral and dissatisfaction because of performance is not considered.

- Many factor that affecting compensation: government rule, regulation, procedures of the organization and organization's capacity to pay.

\section{Conclusion}

On the basic research questions, there are different factors that affect compensation systems that are organization ability to pay, government rule and organization manger. The employee's compensation of Wolaita Sodo private banks is not as such effective according to their working conditions, working structures and time management systems. It is tested by criteria's such as the compensations are not as such adequate, equitable, balanced, cost effective, secure to pay, incentive providing pay and acceptable by employees.

The result of effective compensation plans of private banks employees are satisfied by their basic salary becomes productive workers and the organization attracts qualified employees.

Generally, the compensation plans in is affected by different factors and based on the criteria the workers are productive. Therefore, I conclude the compensation plans of private banks are effective.

\section{Recommendation}

Compensation system is needed to attract and retain employees. So in order to utilize the compensation effectively, I recommend that: if it is effective compensation available to the workers/experts, it is better to compensate based on employees performance and it avoids employees dissatisfaction and increases employee's moral.

If the private banks compensation is effective, it is better to compensate employees based on the on their work effort rather than use centralized compensation system. I advise them advice compensation is better for organizations provided frequently to motivate, compensate employees and they have a better achievement for the organizations' success. It is better the organization to the private bank sectors to improve the payment according to their contribution in the organization due to sustainability. When the government changes and proclaims the new things in monetary system or making very high the public sectors, there are more probability to the experts to shift. That any private bank sector should look critically what the government have been doing in view point of compensations, salaries and other benefits.

\section{References}

1. Kim H, Sutton KL, Gong Y (2001) Group-based Pay-for-performance Plans and Firm Performance: The Moderating Role of Empowerment Practices. Asia Pacific Journal of Management, pp: 1-22.

2. Schwind H, Das H, Wagar T (2004) Human Resource Management of strategic approach. Saint Mary's University.

3. https://www.collinsdictionary.com/dictionary/english/compensation

4. Bernardin HJ (2010) Human resource management an experimental approach Florida Atlantic University.

5. Workie B, Melese ME (2006) Introduction to Management. Addis Ababa University.

6. Benardin (2010) Compensation for Quality Work. Asian Printing Press.

7. Armstrong M (2001) Strategic Human Resource Management: A Guide to action. United Kingdom: Cogan Page Limited.

8. Thomas and Scarpello (2000) Factors Affecting Compensation Sources UNAR.

9. Colonel, Singh N (2011) Human Resource management. University science press.

10. Kothari CR (2004) Research Methodology: Methods \& Techniques. New Age International Publishers.

11. Namasivayam K, Miao L, Zhao X (2007) An Investigation of the Relationship between Compensation Practices and Firm Performance in the US Hotel Industry. International Journal of Hospitality Management 26: 574-597.

12. Invancevich JM (1998) The outcome of employee Compensation. AMUL.

13. Ivancevich JM (2010) Human resource management. C.T. Bauer College of business university of Houston.

14. Dunlop J (2017) Compensation Values. Howard St. San Francisco.

15. Loyd LB Rue LW (2004) Human Resource Management. Georgia University.

16. Noe RA, Hollenbeck JR, Gerhard B, Wright PM (2005), Human Resource Management, Gaining competitive advantage. Ohio state university.

17. Rayton BA (2003) Firm Performance and Compensation Structure: Performance Elasticity of Average Employee Compensation. Journal of Corporate Finance 9: 333-352.

18. Hodgetts RM, Luthans F (2000) International Management. Florida International University.

19. Schcermerhorn and Chappel (2000) Effective Compensation System and Its Objectives.

20. Robbins SP, Duecento DA (2004) Fundamentals of management. San Diego state USA.

21. Baker GP, Jensen MC, Murphy KJ (1988) Compensation and Incentives: Practice Versus Theory. Journal of Finance 43: 593-616. 